\title{
EFEKTIVITAS RENCANA PELAKSANAAN PEMBELAJARAN MATEMATIKA BERBASIS KONSTRUKTIVISME DI SEKOLAH MENENGAH PERTAMA
}

\author{
Uffun Ainullia Manan dan Sabar Narimo \\ Magister Administrasi Pendidikan Sekolah Pascasarjana \\ Universitas Muhammadiyah Surakarta \\ uffun.ndewo64@gmail.com
}

\begin{abstract}
The purposes of this study are: (1) to describe the RPP Mathematics learning device, (2) to describe the development of the RPP Mathematics learning device based on Constructivism, (3) to test the effectiveness of the development of RPP Mathematics learning device based on constructivism. This research is a research development. Triangulation techniques are used to collect data with participative observation methods, in-depth interviews, documentation and tests. Data analysis techniques consist of two components, namely data reduction and data presentation. Results and discussion of the research are (1) the components of RPP Mathematicsthat applied still uses RPP Mathematics school in general, in the core activities the students have not maximally built their own knowledge for the discovery of new concepts, (2) development of the RPP Mathematics learning device based on Constructivism with learning design includes 5 stages: Orientation, Eliciation, Ideal Restructuring, Use of Ideas, and Reviews that are implemented on core activities, and (3) the value of concept comprehension test using RPP based on Constructivism, the average grade is 79.02 from 70.00. Students who scored $\geq 75$ are 18 students or $78.26 \%$. (Math KKM=75).
\end{abstract}

Keywords: concepts understanding, constructivism, mathematics

\begin{abstract}
Abstrak. Tujuan penelitian ini adalah (1) mendiskripsikan perangkat pembelajaran RPP Matematika (2) Mendiskripsikan pengembangan perangkat pembelajaran RPP Matematika berbasis Konstruktivisme, dan (3) Menguji efektivitas pengembangan perangkat pembelajaran RPP Matematika berbasis Konstruktivisme. Penelitian ini merupakan penelitian pengembangan (Research and Development). Teknik triangulasi digunakan untuk mengumpulkan data dengan metode observasi partisipatif, wawancara mendalam, dokumentasi dan tes. Teknik analisis data terdiri dari dua komponen yaitu reduksi data dan penyajian data. Hasil dan pembahasan dari penelitan adalah (1) perangkat pembelajaran RPP Matematika yang telah diterapkan masih menggunakan RPP Matematika sekolah pada umumnya, pada kegiatan inti siswa belum maksimal membangun sendiri pengetahuannya untuk penemuan konsep baru, (2) pengembangan perangkat pembelajaran RPP Matematika berbasis konstruktivisme dengan desain pembelajaran meliputi 5 tahap yaitu: Orientasi, Eliciasi, Restrukturisasi Ide, Penggunaan Ide, dan Review yang diimplementasikan pada kegiatan inti, dan (3) nilai tes pemahaman konsep menggunakan RPP berbasis Konstruktivisme, nilai rata-rata kelasnya adalah 79,02 dari 70,00. Siswa yang mendapat nilai $\geq 75$ ada 18 siswa atau 78,26\%. $($ KKM Matematika $=75)$.
\end{abstract}

Kata Kunci: konstruktivisme, matematika, pemahaman konsep 


\section{Pendahuluan}

Ciri-ciri matematika secara umum yang disepakati bersama memiliki 6 karakteristik, adalah sebagai berikut: (1) Mempunyai objek yang abstrak yaitu fakta, operasi, konsep, dan prinsip, (2) Berdasar pada perjanjian atau konvensi yang berupa lambanglambang dan istilah-istilah maupun aturan dasar (aksioma), (3) Tersusun pola pikir deduktif, (4) Sesuai teknik prosedurnya, (5) Mempunyai lambang kosong dari arti, (6) Mempertimbangkan semesta pembicaraan. (Sumardyono, 2006:30).

Tujuan pertamapembelajaranmatematika adalah agar peserta didik memahami konsep matematika, mendeskripsikan hubungan antar konsep dan menerapkan konsep atau algoritma, secara luwes, cermat, efisien, dan tepat dalam pemecahan masalah. (Depdiknas, 2007:8). Dalam menghadapi masalah - masalah matematika sesuai dengan tujuan diatas, diharapkan siswa dapat menggunakan kemampuan tersebut dalam memahami suatu konsep matematika dalam proses pembelajaran. Kemampuan generalisasi serta abstraksi yang cukup tinggi, sangat diperlukan dalam memahami konsep matematika. Sementara pemahaman siswa terhadap konsep - konsep matematika masih lemah bahkan dipahami dengan keliru. Maka akan berpengaruh pada kualitas belajar siswa yang berakibat pada prestasi belajarnya di sekolah. Tuntutan kurikulum 2006 bahwa kemampuan pemahaman konsep merupakan bagian yang sangat urgen dalam belajar matematika, dan diperlukan kompetensi dalam mencapai hasil belajar matematika. Pemahaman terhadap konsep matematika yang baik harus diefektifkan dan dikembangkan melalui pembelajaran matematika di kelas.Seharusnya semua siswa memiliki kemampuan pemahaman konsep secara memadai, mengingat pentingnya peranan kemampuan tersebut dalam pembelajaran matematika.

Berdasarkan hasil pengamatan dan wawancara dengan teman sejawat sesama guru di SMP Negeri 1 Kemusu bahwa setiap ulangan harian hasilnya kurang memuaskan, siswa masih kurang memahami konsep konsep matematika yang telah diajarkan, antara lain siswa belum mampu menyebutkan kembali suatu konsep, mengelompokkan objek menurut sifat- sifatnya sesuai dengan konsep dan menyebutkan contoh atau bukan contoh. Kurangnya pemahaman siswa terhadap suatu konsep matematika berdampak pada hasil belajar yang diperoleh kurang memuaskan.

Siswa cenderung merasa takut dan enggan mengemukakan pendapat maupun pertanyaan, dalam mengikuti proses pembelajaran matematika di kelas, pengetahuan yang diterima siswa secara pasif menjadikan matematika itu tidak bermakna bagi siswa. Dalam ringkasan tesis Syukur (2006:8) bahwa pembelajaran berbasis behaviorisme mendominasi di Indonesia pada kelas-kelas matematika selama ini, yaitu dengan mengutamakan pada transfer pengetahuan dan penyelesaian soal-soal. Interaksi searah kurang memperhatikan aktifitas siswa, dan pengkontruksian konsep tidak melibatkan siswa. Guru hendaknya selalu menggali dan mengungkap kembali kemampuan awal yang dimiliki siswa agar ada korelasi antara informasi lama dengan informasi baru.

Persiapan guru mengajar yang berupa perangkat pembelajaran adalah salah satu penyebabnya. Guru masih menggunakan perangkat pembelajaran yang selama ini digunakan. Perangkat pembelajaran berorientasi konstruktivisme dapat dijadikan sebagai salah satu alternatif persiapan guru dalam mengajar sehingga dapat meningkatkan kemampuan pemahaman konsep matematika siswa.

Pembelajaran konstruktivisme adalah suatu perubahan konseptual, yang dapat berupa membangun ide baru atau membangun ide yang sudah ada sebelumnya. Menurut Fitriyani (2014:9) dalam tesisnya bahwa pembelajaran konstruktivisme adalah 
suatu pendekatan pembelajaran yang dapat menjawab cara belajar siswa aktif dan membangun pemahaman.

Pembelajaran yang menggunakan pendekatan konstruktivisme, siswa dapat terlibat secara aktif dengan materi pelajaran melalui interaksi sosial yang terjadi didalam kelas. Aktivitas yang dilakukan adalah kegiatan mengamati fenomena, mengumpulkan data-data, merumuskan dan menguji hipotesis, dan bekerjasama dengan orang lain (Wardoyo, 2013:29).

Sedangkan menurut Schucnk, 2012 (dalam Wardoyo, 2013:23) melalui pembelajaran konstruktivisme mengarahkan pada proses pembelajaran penemuan konsep yang lahir dari pandangan, dan gambaran serta inisiatif siswa. Hal ini sesuai dengan pandangan konstruktivisme bahwa siswa membangun sendiri pengetahuannya secara aktif dengan memperhatikan pengetahuan awal siswa.

Dengan demikian perlu adanya perubahan paradigma dalam pembelajaran, khususnya paradigma pembelajaran di sekolah. Paradigma alternatif untuk memecahkan masalah pembelajaran matematika di sekolah adalah paradigma konstruktivistik. Dengan prinsip-prinsip konstruktivisme sebagai berikut (1) siswa membangun sendiri pengetahuannya secara pesonal maupun sosial, (2) pengetahuan tidak dapat dipindahkan begitu saja ke siswa dari guru, kecuali dengan keaktifan siswa sendiri dalam menalar, (3) siswa aktif membangun sendiri pengetahuanya secara terus menerus, sehingga terjadi perubahan konsep menuju konsep yang lebih fokus, lengkap, dan sesuai kaidah ilmiah, (4) guru sebagai fasilitator dalam melayani proses pembentukan. (Suparno, 1998:73).

Bertitik tolak dari temuan di atas, perlu dilakukan upaya perbaikan terhadap pelaksanaan pembelajaran matematika di kelas dengan mengembangan perangkat pembelajaran matematika yang sesuai dengan karakteristik pembelajaran konstruktivisme. Perangkat pembelajaran yang dikembangkan adalah rencana pelaksanaan pembelajaran (RPP) dengan mengintegrasikan langkahlangkah pembelajarannya yang berbasis Konstruktivisme, dalam setiap pembahasan materi dan tes hasil belajar siswa untuk mengetahui keefektifan hasil pengembangan RPP.

Rencana perangkat pembelajaran (RPP) Matematika yang dikembangkan dalam penelitian ini mengacu dari pendapat Suparno, dengan tahapan pembelajaran konstruktivisme sebagai berkut:

a. Tahap Orientasi

Siswa diberi kesempatan untuk mengembangkan motivasi dalam mempelajari suatu topik. Siswa diberi kesempatan untuk mengadakan observasi terhadap topik yang hendak dipelajari.

b. Tahap Eliciasi

Siswa dibantu untuk mengungkapkan idenya secara jelas dengan berdiskusi, membuat poster, menulis, dan lainlain, dan diberi kesempatan untuk mendiskusikan apa yang diobservasikan, dalam bentuk tulisan, poster, ataupun gambar.

c. Tahap Restrukturisasi Ide

1) Klarifikasi ide yang dicocokan dengan ide-ide antar siswa melalui diskusi atau pengumpulan ide, sehingga siswa termotivasi untuk merekonstruksi gagasannya kalau tidak cocok atau sebaliknya, menjadi lebih yakin bila gagasannya cocok.

2) Membangun ide yang baru. Apabila dalam diskusi terjadi bertentangan atau tidak dapat menjawab pertanyaan-pertanyaan yang diajukan teman-teman.

3) Mengevaluasi ide barunya dengan eksperimen. Jika memungkinkan, sebaiknya gagasan yang baru dibentuk itu dilakukan suatu percobaan atau persoalan yang baru.

d. Tahap Penggunaan Ide Dalam Banyak Situasi

Ide atau pengetahuan yang telah dibentuk oleh siswa perlu diaplikasikan 
pada bermacam-macam situasi. Hal ini akan membuat pengetahuan siswa lebih lengkap dan rinci.

e. Tahap Review

Aplikasikan pengetahuannya dalam situasi yang dihadapi sehari-hari, sehingga memungkinkan untuk merevisi gagasannya dengan menambah keterangan atau mungkin mengubah menjadi lebih lengkap.Driver \& Oldam (dalam Suparno, 1998:69)

Adapun salah satu dari tujuan penelitian ini adalah menguji keefektifan pengembangan perangkat pembelajaran RPP (Rencana Pelaksanaan Pembelajaran) Matematika berbasis konstruktivisme di Sekolah Menengah Pertama.

\section{Metode}

Penelitian ini merupakan penelitian pengembangan (Research and Development). Menurut Sutama (2012:183) Penelitian dan pengembangan adalah suatu proses atau langkah-langkah untuk mengembangkan suatu produk baru atau menyempurnakan produk yang sudah ada yang dapat dipertanggungjawabkan.

Subyek penelitian ini adalah peserta didik Sekolah Menengah Pertama Negeri 1 Kemusu Boyolali tahun pelajaran 2015/2016. Peserta yang dijadikan subyek penelitian adalah peserta didik kelas VIII B.

Jenis data yang diperoleh dari penelitian ini adalah data kualitatif berupa perangkat pembelajaran RPP Matematika yang selama ini di laksanakan dan RPP Matematika yang akan dikembangkan di SMP Negeri 1 Kemusu. Sedangkan data kuantitatifdiperoleh dari hasil evaluasi belajar pada pada siklus 1 sebagai pretes yang akan digunakan untuk mengukur kemampuan awal siswa, sedangkan pada siklus 2 sebagai postes. Untuk menentukan keefektifan menggunakan RPP yang dikembangkan dengan membandingkan antara rataan hasil pre test dan post tes.

Teknik yang digunakan untuk mengumpulkan data menggunakan teknik triangulasi. Triangulasi teknik berarti peneliti menggunakan teknik pengumpulan data yang berbeda-beda untuk mendapatkan data dari sumber data yang sama (Sugiyono, 2013:330). Peneliti menggunakan metode observasi partisipasif, wawancara, dokumentasi dan tes, untuk sumber data yang sama secara serentak. Teknik analisis data yang digunakan dengan analisis deskripsi kualitatif dan kuantitatif.

\section{Hasil dan Pembahasan}

Persiapan yang dilakukan guru salah satunya adalah menyusun RPP (Rencana Pelaksanaan Pembelajaran), sebelum awal semester dimulai. Pertama kali yangdilaksanakan adalah menganalisis silabus sehingga dapat mengarah kepada Kompetensi Dasar yang dimaksud. Selanjutnya mengisi nama mapel (mata pelajaran) yang sesuai dan alokasi waktu yang telah ditetapkan. Menentukan Standar Kompetensi, Kompetensi Dasar dan indikator yang terdapat pada silabus yang ada. Dan juga tujuan pembelajaran, materi ajar, metode pembelajaran, merumuskan langkah-langkah kegiatan pembelajaran dari pendahuluan hingga penutup, berikut alat dan sumber belajar yang digunakan.

Pernyataan di atas sesuai dengan hasil penelitian yang dilakukan oleh Devyanik Raval (2013), menunjukkan bahwa penting bagi semua guru untuk wajib membuat rencana pelaksanaan pembelajaran sebelum memulai proses belajar mengajar agar pembelajaran lebih efektif dan produktif.

Hasil penelitian perangkat pembelajaran RPP berbasis Konstruktivisme mempunyai model sintak pembelajaran Konstruktivisme sebagai berikut: 
Tabel 1. Sintaks Model Pembelajaran Konstruktivisme

\begin{tabular}{|c|c|c|}
\hline No & $\begin{array}{l}\text { Tahap Pembelajaran } \\
\text { Konstruktivisme }\end{array}$ & Kegiatan Pembelajaran \\
\hline 1 & Orientasi & $\begin{array}{l}\text {-Mengembangkan motivasi dalam } \\
\text { mempelajari suatu topik } \\
\text {-Mengamati / observasi }\end{array}$ \\
\hline 2 & Eliciaci & -Menuliskan hasil pengamatan \\
\hline 3 & Restrukturisasi Ide & $\begin{array}{l}\text {-Klarifikasi ide } \\
\text {-Membangun ide } \\
\text {-Mengevaluasi ide baru }\end{array}$ \\
\hline 4 & $\begin{array}{l}\text { Penggunaan Ide/ Penerapan } \\
\text { Ide }\end{array}$ & $\begin{array}{l}\text {-Mengerjakan soal latihan } \\
\text {-Mengerjakan soal sesuai dengan konsep } \\
\text { yang digunakan }\end{array}$ \\
\hline 5 & Review & $\begin{array}{l}\text {-Mengaplikasi pengetahuan untuk merevisi, } \\
\text { menambah, atau mengubah gagasannya } \\
\text { menjadi lebih lengkap. }\end{array}$ \\
\hline
\end{tabular}

Peneliti menyusun perangkat pembelajaran yaitu Rencana Pelaksanaa Pembelajaran (RPP) Matematika yang akan digunakan yang terdiri dari 2 pertemuan. Perangkat yang dikembangkan adalah Rencana Pelaksanaan Pembelajaran (RPP) Matematika berbasis Konstruktivisme dengan materi Bangun Ruang Sisi Datar. Pada Standar Kompetensi: 5. Memahami sifat-sifat kubus, balok, prisma, limas, dan bagian-bagiannya, serta menentukan ukurannya. Kompetensi Dasar: 5.3 Menghitung luas permukaan dan volum kubus, balok, prisma dan limas. Untuk RPP-1 dengan indikator: (1) menemukan rumus luas permukaan kubus, (2) menghitung luas permukaan kubus, dan (3) menyelesaikan soal cerita dalam kehidupan sehari-hari yang berkaitan dengan luas permukaan kubus. Sedangkan RPP-2 dengan indikator: (1) menemukan rumus luas permukaan balok, (2) menghitung luas permukaan balok, dan (3) menyelesaikan soal cerita dalam kehidupan sehari-hari yang berkaitan dengan luas permukaan balok.Kemudian menyusun lembar validasi penilaian dan pengembangan Rencana Pelaksanaan Pembelajaran (RPP). Selanjutnya untuk mengetahui efektifitas RPP pengembangan dipersiapkan kisi-kisi soal, soal tes pemahaman konsep dan kunci jawaban dan rubrik penskoran.

Sebelum pelaksanaan pembelajaran pada siklus kedua RPP pengembangan divalidasi terlebih dahulu oleh dua guru matematika SMP Negeri 1 Kemusu menggunakan lembar validasi penilaian dan pengembangan RPP.

Kegiatan pembelajaran pada siklus kedua yang dilakukan pada tahapan ini meliputi kegiatan pendahuluan, kegiatan inti dan kegiatan penutup. Kegiatan pendahuluan, pada pembelajaran tahap pengembangan ini guru mengawali pembelajaran dengan menyampaikan tujuan pembelajaran kepada peserta didik. Penyampaian tujuan pembelajaran disampaikan dengan lengkap. Tujuan dari materi yang diberikan adalah peserta didik dapat : (1) menemukan rumus luas permukaan kubus, (2) menghitung luas permukaan kubus, dan (3) menyelesaikan soal cerita dalam kehidupan sehari-hari yang berkaitan dengan luas permukaan kubus. Kemudian guru menyampaian apersepsi dan motivasi. Pada kegiatan apersepsi menghubungkan materi yang telah dipelajari pada pertemuan sebelumnya, dan mengkaitkannya dengan materi yang akan dipelajari. Dan pada kegiatan motivasi, guru menyampaikan manfaat mempelajari luas permukaan kubus yang dikaitkan dengan kehidupan sehari-hari.

Kegiatan inti terbagi menjadi tiga tahapan yaitu eksplorasi, elaborasi dan konfirmasi. Pada kegiatan pengembangan menggunakan pendekatan pembelajaran berbasis Konstruktivisme sehingga terdapat 
tahapan kegiatan pada eksplorasi, elaborasi dan konfirmasi.

Pada kegiatan eksplorasi, terdapat tahap Orientasi dimana guru melakukan kegiatan yang membangkitkan rasa ingin tahu peserta didik, dengan memberi permasalahan :“ Misalkan, kamu ingin membuat kotak makanan berbentuk kubus dari selembar karton dengan ukuran tertentu". Berapa luas karton yang dibutuhkan untuk membuat kotak makanan, jika rusuknya memiliki ukuran tertentu? Masalah ini dapat diselesaikan dengan cara menghitung luas permukaan kubus.

Kemudian guru membagikan LKK-1 kepada peserta didik untuk mengamati pada Kegiatan-1 tentang menemukan rumus luas permukaan kubus.

Pada Elaborasi, terdapat tahap Eliciasi dimana setelah peserta didik melakukan kegiatan pengamatan kemudian menuliskan hasil pengamatan atau observasi pada Lembar Kegiatan Kerja (LKK) dengan penuh semangat. Selanjutnya pada tahap Restrukturisasi Ide, peserta didik dengan anggota kelompoknya saling bekerja sama bertukar ide untuk menjawab pertanyaan pada kegiatan diskusi, saling menghargai pendapat dari teman-teman dalam kelompoknya dengan penuh perhatian.

Pada kegiatan tersebut peserta didik melakukan sendiri dalam mengkonstruksi dan menemukan rumus luas permukaan kubus dengan cara mengintegrasikan ide yang mereka miliki, sehingga pembelajaran menjadi lebih bermakna karena peserta didik mengerti dan mempunyai kesempatan untuk berdiskusi dan saling bertukar pengalaman dan ilmu pengetahuan dengan temannya. Dengan menemukan sendiri rumus luas permukaan kubus, maka akan lama tersimpan dalam ingatan siswa.

Pada kegiatan konfirmasi, dilaksanakan presentasi hasil diskusi kelompok, salah satu kelompok untuk mempresentasikan hasil diskusi dengan penuh tanggung jawab dan percaya diri , sedangkan siswa dari kelompok lain menanggapi, dengan bimbingan guru untuk merumuskan jawaban yang benar. Guru memberikan pujian kepada kelompok yang sudah bersedia mempresentasikan hasil diskusi di depan kelas dan memotivasi kepada kelompok lain yang belum memiliki kesempatan untuk mempresentasikan hasil diskusinya.

Pada tahap Penggunaan Ide, peserta didik menggunakan pengetahuannya untuk penerapakan konsep yang diperolehnya dengan mengerjakan latihan soal-soal yang sesuai dengan indikator pencapaian kompetensi pada luas permukaan kubus LKK-1 dengan penuh tanggung jawab dan semangat. Bila perlu guru memberi bimbingan, sedangkan pada tahap Review, guru dan siswa mengkonfimasi jawaban yang benar mengenahi luas permukaan kubus dengan tanya jawab.

Untuk kegiatan penutup, guru memberikan motivasi tentang materi yang telah dipelajari dan mengulang kembali materi tersebut agar lebih mudah untuk dipahami , kemudian bersama-sama guru membimbing siswa untuk membuat kesimpulan rumus luas permukaan kubus. Sebelum mengakhiri kegiatan, siswa diberi tugas rumah berupa soal luas permukaan kubus dan mempelajari kembali unsur-unsur dan jaring-jaring balok, untuk mempersiapan materi pada pertemuan berikutnya.

Untuk mengakhiri kegiatan pembelajaran dengan menggunakan waktu khusus, siswa diberi soal tes pemahaman konsep dalam bentuk soal uraian yang mengacu pada 7 indikator pemahaman konsep (Tim PPPG matematika, 2005), untuk mengetahui kefektifan dari RPP pengembangan.

Pada tahap pelaksanaan, sebelum adanya pengembangan, penemuan konsep baru didominasi guru, dan setelah menggunakan RPP yang dikembangkan guru melibatkan siswa secara aktif dan memfasilitasi dalam kegiatan pembelajaran untuk dapat membangun sendiri dalam penemuan konsep. Seperti di gambarkan pada tabel berikut ini. 
Tabel 2. Tahapan Sebelum dan Sesudah Pengembangan RPP

\begin{tabular}{|c|c|c|}
\hline $\begin{array}{l}\text { Tahapan } \\
\text { Kegiatan }\end{array}$ & Sebelum Pengembangan & Pengembangan \\
\hline
\end{tabular}

Eksplorasi

Konfirmasi
1. Dengan ceramah dan tanya jawab menemukan rumus luas permukaan kubus.

2. Dengan ceramah dan tanya jawab membahas luas permukaan kubus.
1. Guru mengkondisikan kembali kelompokkelompok yang sudah terbentuk pada pertemuan sebelumnya.

\section{Tahap 1 : Orientasi}

2. Untuk membangkitkan rasa ingin tahu siswa, guru memberi masalah pada LKK-1. Guru memancing siswa dengan pertanyaan "Berapa luas karton yang dibutuhkan untuk membuat kotak makanan?"

Kemudian mendiskusikan Kegiatan-1 pada LKK-1

3. Siswa mengamati Lembar Kegiatan Kerja-1

\section{Tahap 2 : Eliciasi}

3. Guru membentuk kelompok beranggotakan $4-6$ siswa.

Elaborasi 4. Memberikan soal untuk bahan diskusi masing-masing kelompok.

4. Siswa menuliskan hasil pengamatan pada Lembar Kegiatan Kerja (LKK).

\section{Tahap 3 : Restrukturisasi Ide}

5. Siswa bekerja sama dengan anggota kelompoknya saling bertukar ide untuk menjawab pertanyaan pada kegiatan diskusi

6. Perwakilan kelompok mempresentasikan hasil diskusinya, siswa dari kelompok lain menanggapi dengan bimbingan guru untuk merumuskan jawaban yang benar.

5. Dari hasil diskusi, salah seorang siswa dalam suatu kelompok mempresentasikan hasil diskusinya dan kelompok yang lain menanggapi dengan bimbingan guru untuk merumuskan jawaban yang benar.

6. Siswa mengerjakan soal latihan secara individual. Guru membimbing bila perlu.
7. Guru memberikan pujian kepada kelompok yang sudah bersedia mempresentasikan hasil diskusi di depan kelas dan memotivasi kepada kelompok lain yang belum memiliki kesempatan untuk mempresentasikan hasil diskusinya.

\section{Tahap 4 : Penggunaan Ide}

8. Siswa menggunakan pengetahuannya untuk penerapakan konsep yang diperolehnya dengan mengerjakan latihan soal-soal pada LKK-1. Bila perlu guru memberi bimbingan

\section{Tahap5: Review}

9. Guru dan siswa mengkonfimasi jawaban yang benar mengenahi luas permukaan kubus.
Berdasarkan hasil observasi pada tahap pelaksanaan pembelajaran matematika dengan menggunakan RPP berbasis Konstruktivisme, pada kegiatan inti tahap eksplorasi terdapat kegiatan orientasi, guru melibatkan siswa secara aktif dan memfasilitasi dalam kegiatan pembelajaran untuk mencari informasi yang luas dan dalam pada materi yang akan dipelajari.
Tahap eksplorasi guru memfasilitasi pemberian tugas dengan berdiskusi secara kelompok dan memberi kesempatan berpikir, menganalisis, menyelesaikan masalah. Sehingga siswa dalam memahami suatu konsep dengan cara membangun sendiri pengetahuannya di dalam benaknya, melalui pemberian tugas. Guru memfasilitasi dan memberikan kemudahan untuk proses ini, 
dengan memberikan kesempatan siswa untuk menemukan atau menerapkan ide-ide mereka sendiri, dan mengajar siswa menjadi sadar dan secara sadar menggunakan strategi mereka sendiri untuk belajar. Dengan pembelajaran berbasis
Konstruktivisme mampu membelajarkan peserta didik.

Dari pembelajaran pada siklus pertama dan kedua diperoleh hasil nilai tes pemahaman konsep matematika yang disajikan dalam grafik dibawah ini.

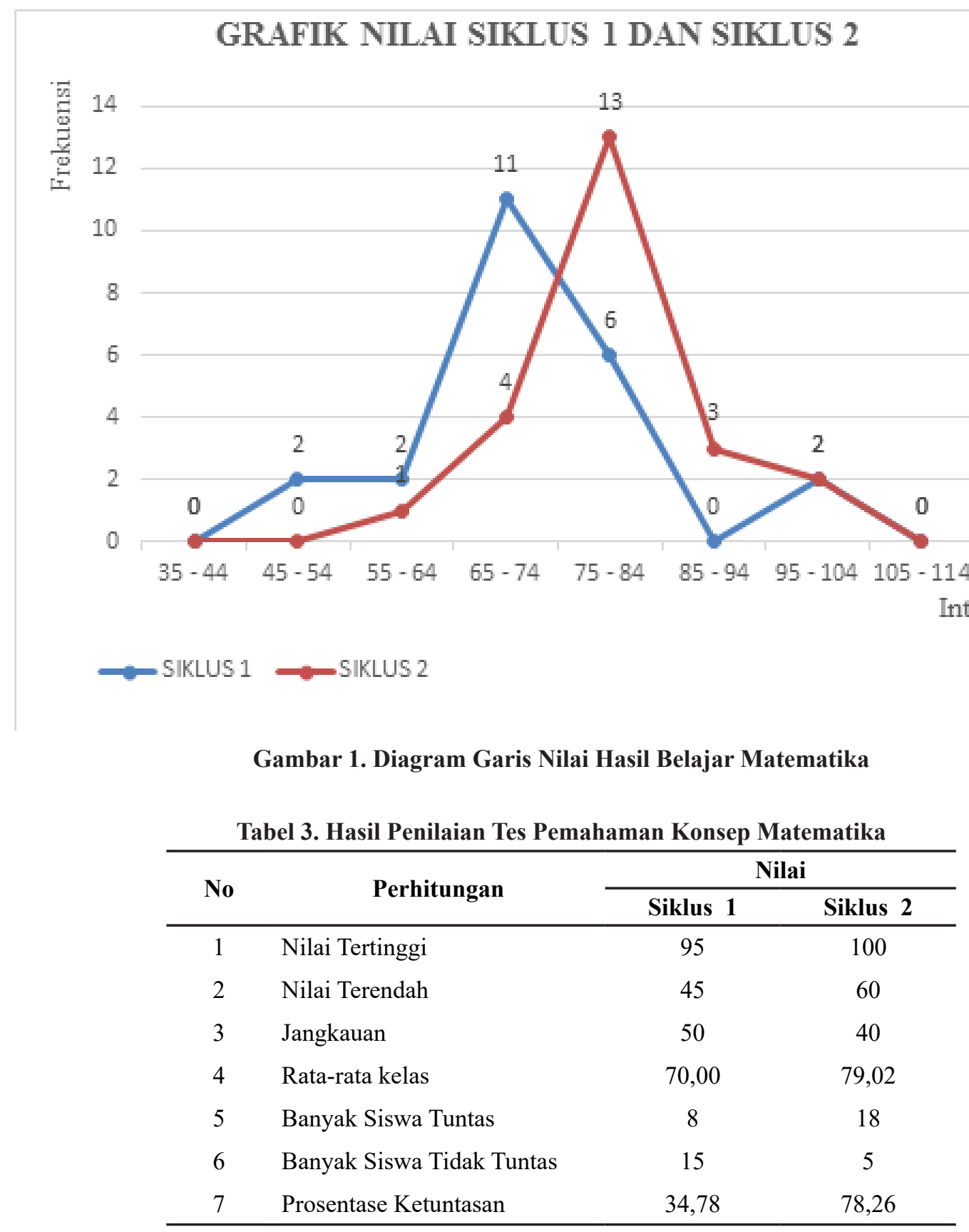

Berdasarkan grafik tersebut diatas, 4 siswa sehingga terjadi penurunan sebanyak pembelajaran matematika pada siklus 7 siswa, artinya pada interval tersebut yang pertama jumlah yang memperoleh nilai $<$ mendapat nilai diatas 65 kurang dari 74 75 ada 15 siswa dari 23 siswa. Pada Interval kelas $65-74$ pada siklus pertama terdapat 11 siswa sedangkan pada siklus kedua terdapat meningkat secara signifikan sebanyak 7 siswa. Pada Interval kelas $75-84$ pada siklus pertama terdapat 6 siswa sedangkan pada 
siklus kedua terdapat 13 siswa, sehingga terdapat peningkatan nilai sejumlah 7 siswa.

Secara komulatif pada pembelajaran matematika pada siklus pertama nilai pemahaman konsep matematika siswa kelas VIII B yang memperoleh nilai $\geq 75$ ada 5 siswa atau 34,78 \% dan pada siklus kedua yang memperoleh nilai $\geq 75$ ada 18 siswa atau 78,26\% (KKM Matematika $=75)$, sehingga pada siklus kedua secara klasikal pembelajaran matematika adalah tuntas.

Dengan demikian pembelajaran menggunakan RPP (Rencana Pelaksanaan Pembelajaran) Matematika berbasis Konstruktivisme efektif dilaksanakan di SMP Negeri 1 Kemusu. Peningkatan secara umum pada siklus pertama dan kedua dapat dilihat pada tabel 3.

Hasil pembelajaran menggunakan RPP (Rencana Pelaksanaan Pembelajaran) berbasis Konstruktivisme selain dapat meningkatkan pemahaman konsep matematika siswa, melalui interaksi sosial dapat pula meningkatkan percaya diri siswa, tanggunggung jawag, daya ingat, mempunyai rasa empati, toleransi dan aktif mengikuti pembelajaran matematika.

Dengan demikian pembelajaran menggunakan Rencana Pelaksanaan Pembelajaran (RPP) Matematika berbasis
Kontruktivisme efektif dikembangkan di SMP Negeri 1 Kemusu.

\section{Simpulan}

Pengembangan perangkat pembelajaran yang dikembangkan adalah RPP yang selama ini digunakan di SMP Negeri 1 Kemusu yaitu RPP berbasis Konstruktivisme dengan desain pembelajaran meliputi 5 tahap yaitu : Orientasi, Eliciasi, Restrukturisasi Ide, Penggunaan Ide, dan Review yang diimplementasikan pada kegiatan inti sebagai berikut : (a) kegiatan eksplorasi terdapat tahap orientasi, (b) kegiatan elaborasi terdapat tahap eliciasi dan restrukturisasi ide dan (c) kegiatan konfirmasi terdapat tahap penggunaan ide dan review. Dengan RPP berbasis Konstruktivisme pemahaman konsep matematika siswa meningkat, selain itu meningkat pula percaya diri siswa, tanggung jawab, daya ingat, toleransi, rasa tanggung jawab dan lebih aktif dalam pembelajaran matematika.

Rencana Pelaksanaan Pembelajaran (RPP) Matematika berbasis Kontruktivisme efektif dalam pembelajaran pada siswa di SMP Negeri 1 Kemusu. Nilai rata-rata kelasnya adalah 79,02 dari 70,00. Siswa yang mendapat nilai $\geq 75$ ada 18 siswa atau 78,26 $\%$. $($ KKM Matematika $=75)$.

\section{Daftar Pustaka}

Departemen Pendidikan Nasional. 2006. Standar Isi, Mata Pelajaran Matematika Sekolah Menengah Pertama dan Madrasah Tsanawiyah.

Fitriyani, A. 2014. Pengaruh Model Pembelajaran Konstruktivisme Menggunakan Komputer Terhadap Hasil Belajar Siswa Pada Konsep Cahaya. Skripsi. Jakarta: UIN Syarif Hidayatullah.

Hamzah. 2008. Teori Belajar Konstruktivisme.http://akhmadsudrajat.wordpress. com/2008/08/20/teori-belajar-konstruktivisme/ (diunduh 4 Maret 2016, jam 15.16

Mulyasa, E. 2012. Kurikulum Tingkat satuan Pendidikan. Bandung: Rosdakarya.

Peraturan Menteri Republik Indonesia Nomor 41 Tahun 2007 tentang StandarProses Untuk Satuan Pendidikan Dasar Dan Menengah.

Raval, K.D. 2013. Lesson Plan: Blueprint of Teaching. International Journal for Research in Education. Vol. 2. Issue: 2

Robertson, W.H., Meyer, R.D.,\& Wilkerson,T.L. 2012. The Mathematics of Skateboarding: A Relevant Application of the 5Es of Constructivism. Journal of Education and Learning; 
Vol. 1, No. 2; 2012. Published by canadian center of Science and Education.

Samsulhadi, 2010. Teori Konstruktivisme dalam Pembelajaran. http://smpn1 gumukmas01. blogspot.co.id/2010/07/normal-0-false-false-false-en-us-X-none.html(diunduh 5 Maret 2016 jam 12.21).

Sugiyono. 2013. Metode Penelitian Pendidikan: Pendekatan Kuantitatif, Kualitatif, dan $R \& D)$. Bandung: Alfabeta.

Sumardyono. 2004. Karakteristik Matematika Dan Implikasinya Terhadap Pembelajaran Matematika. Yogyakarta : Pengembangan Penataran Guru Matematika

Suparno, P. 1998. Filsafat Konstruktivisme Dalam Pendidikan. Jakarta : Kanisius.

Supinah. 2008. Penyusunan Silabus dan Rencana Pelaksanaan Pembelajaran(RPP) Matematika SD dalam Rangka Pengembangan KTSP. Yogyakarta: Pusat Pengembangan dan Pemberdayaan Pendidik dan Tenaga Kependidikan Matematika.

Sutama, 2015. Metode Penelitian Pendidikan: Kuantitatif, Kualitatif, PTK, $R \&$ D. Surakarta: Fairuz Media.

Syukur, A. 2006. Mengembangkan Kemampuan Kritis melalui Pembelajaran Matematika dengan Pendekatan Open Ended. Tesis. Bandung: PPS UPI.

Wardoyo, S.M. 2013. Pembelajaran Konstruktivisme. Bandung: Alfabeta.

Widoyoko, S.E.P. 2014. Evaluasi Program Pembelajaran. Yogyakarta: Pustaka Pelajar. 